\title{
The Research on College English Teaching Guided by the General Education Idea
}

\author{
Jianrong Li \\ Heihe University \\ Heihe, Heilongjiang, China
}

\author{
Hui Xie \\ Heihe University \\ Heihe, Heilongjiang, China
}

\begin{abstract}
The college English teaching innovation is going off in the direction of cultivating college students' English comprehensive practical abilities and cultural attainments. The general education aims to cultivate individuals with comprehensive qualities, abilities of cross-cultural communication and unique thinking. Therefore, applying the general education idea to college English teaching is consistent with the direction of current English teaching innovation, which enables to meet the social demand for compound English talents. Combining with college English teaching practice, the article has put forward the innovation strategies on applying the general education idea to college English teaching. Meanwhile, the article has also analyzed the difficulties emerged during the application course and offered some constructive suggestions.
\end{abstract}

Keywords-the general education idea; college English teaching; college English teachers; the course design

\section{INTRODUCTION}

The College Foreign Language Teaching Guidance Committee of Higher Institutions in Education Ministry officially studied and drew up the College English Teaching Guide in order to further the college English teaching innovation in 2013. The College English Teaching Guide says, "The teaching objectives of college English teaching are to cultivate students' abilities of practicing English and to enhance cross-cultural communication awareness and abilities of communicating. Meanwhile, the objectives are to develop students' abilities of studying on their own and to improve their comprehensive cultural attainments so that they can use English effectively in their study, life, social communication and future careers, which meets with the demands of our country, society, schools and individuals." [1] Seen from the teaching objectives in The College English Teaching Guide, college English teaching should do play its role in higher education on the situation that the current higher education advocates returning back to the essence of education, which needs to present the nature of humanism and instrumentalism as well as its universal nature.

The college English teaching objectives guided by the general education idea coincide with the ones drawn up in the College English Teaching Guide. The general education idea emphasizes students' all-round growth of comprehensive qualities, cultivation of humanism, perfection of personalities and improvement of cultivation to train students to become

This article is the research result of the English specialized teaching innovation project of Heilongiang higher institutions in 2015, The Research on Application of the Teaching Idea in British Higher Education to College English Teaching in China. The project number is 0315002. well-rounded and healthy. General education is a kind of extensive, non-professional and non-utilitarian education of basic knowledge, skills and attitudes which all college students should receive. It aims to cultivate well-rounded individuals that participate in social life actively and have social sense of responsibility[2].

The new century's demand for talents has shifted from single ones to compound ones with comprehensive development of knowledge, capabilities and qualities. The college English teaching guided by the general education idea is the need of the development of the era, which is beneficial to the organical combination of English learning and all-round knowledge learning. It enables to strengthen students' inner cultivation and perfect students' personalities, which is favourable to their sustainable development.

\section{College English Teachers' General EduCATION IDEA}

Selecting a kind of education ideas decides a pattern of education practice and is related to the future of students and society. The ultimate pursuit of applying the general education idea to college English teaching is to exploit students' potential essence and spiritual temperament so as to foster internationalized talents with deeper insight and graceful emotions. In order to realize the general education idea's reasonalbe application to college English teaching, teachers must shift their own idea first. The college English teachers should know and understand the connotation of general education and guide the detailed contents in teaching so that general education is blended into college English courses.

Not only should college English teachers teach language skills and settle the problems of basic theories and views but to cultivate students' cross-cultural sense and critical thinking of western culture. The teachers who guide the teaching practice by the general education idea are undertaking three missions: to help students make up for the deviation of English knowledge structures and improve students' comprehensive cultural qualities; to cultivate students to reorganize and reunite knowledges of different fields so that students can develop from absorbing knowledge to understanding subtlety; to mould students' personalities and cultivate individuals with noble sentiments, high social sense of responsibilities and correct value orientation.

Teachers are the main providers of language input in class. If teachers' knowledge structures are single and are only 
restricted to English specialties and the teachers cannot intersect English with other subjects, the general education idea cannot apply to teaching fully. Therefore, not only should college English teachers master abandant specialties of English but also own better comprehensive qualities and excellent teaching abilities. The college English teachers with the general education idea should focus on language's instrumentalism as well as humanism. Teachers should balance the cultivation of language skills and general education so as to find out the balanced point between instrumentalism and general education.

\section{THE APPLICATION OF THE GENERAL EDUCATION IDEA TO COLLEGE ENGLISH TEACHING}

The college English teachers implement the general education idea in teaching practice to lay solid foundations for the students and extend and balance students' abilities of intelligence. The implementation of the general education idea is realized by means of curriculum. Therefore, the course design is the key to integration of general education and college English teaching.

\section{A. The Teaching Objective of College English Teaching Guided by the General Education Idea}

The teaching objective of college English teaching guided by the general education idea should focus on the harmonious and healthy development of students' life, emotions and morals as well as the cultivation of students' comprehensive abilities. The general education idea is characterized by the times and diversity [3]. Such objectives require students shouldn't confine their knowledge learning to some specific field but to learn knowledge of diverse subjects. They should also follow the times and make adjustments in knowledge structures.

The college English teaching guided by the education idea aims to cultivate all-round talents by means of college English courses and other courses together during the college period but not only to improve the language skills. Thus teachers should put students' all-round development above everything else in teaching and combine language knowledge with allround knowledge learning organically. Abilities of practising English, sense of cross-cultural communication and diverse subject konwledge are the basic elements that talents with high qualities must possess. The English language, the culture at home and abroad and pluralistic subjects should be blended into college English teaching systematically by means of college English courses so that compound English talents with broad humanistic knowledge and qualities are cultivated.

\section{B. To Strengthen the Construction of Potential College English Courses}

The concept of potential courses was first put forward in The Life in Class Learning, written by Jackson, an American educator, in 1968. Jin Yule, a scholar in our country, defined invisible courses in A Brief Argument on Potential Courses as "non-public educational experience, including academic and non-academic, conveyed to students by schools consciously or unconsciously by means of educational environment which includes material, cultural and social relationship environment". [4] The potential college English courses can be carried out and constructed from the following aspects.

1) To hold English lectures regularly: Different scholars consider problems from different angles as a result of their distinct knowledge structures. Therefore, they convey different opinions and ideas to students, which can broaden students' range of knowledge and thinking as well as their critical thinking abilities. Meanwhile, such activity will also play an important role in cultivating students' personalities and promoting teaching qualities.

2) To develop various English extracurricular activities: English contests, English clubs and English extracurricular reading activities, etc, enable to cultivate students' sentiments and broaden students' views. The extracurricular activities provide students with relaxing and pleasurable environment to study English on their own and stimulate students' interest in English. Thus students' cultural attainments and comprehensive abilities can be improved.

3) To construct a beneficial English atmosphere on campus: English corners can be established on campus. Students should be encouraged to subscribe to English newspapers and magazines. Teachers are advised to recommend English works in the original to their students regularly and hold discussions on their understanding gained by reading regularly. Colleges and universities should also often create opportunities to communicate with foreign teachers for students. These measures aim to encourage students to study and help each other forward in a favourable atmosphere so that they can grow into individuals with sound personalities in harmonious development.

The invisible college English course is the extension of classroom teaching, which will exert an invisible, formative influence on students. The courses are favorable to cultivate students' comprehensive and creative abilities and can also play an important role in fostering students' communicating and cooperating capabilities.

4) To construct college English courses based on internet: Informationization has become the mainstream in the development of the current society. Being the foothold of constructing English courses, multimedia teaching and Internet have constructed the platform of English learning online. The college English courses can offer auto-teaching online in order to realize resources sharing. Students are assigned tasks regularly, such as watching valuable English films or writing understanding of the films after watching, etc. Teachers help to solve the problems that students met during the course of self-studying.

The college English courses by means of computers and Internet teaching will decrease teachers' labour intensity and enhance students' self-learning abilities. The resources are shared and the teaching quality has been improved.

5) To establish diverse optional courses and extended courses: Nearly most college English courses are required courses and there are a few optional ones. Such curriculum 
design will halt students' development of individual personalities and also be disadvantageous for arousing students' enthusiasm of learning English. College English teaching is an essential part of general education, in which students should be steered to increase their understanding of foreign cultures and customs. As for the foreign culture, students should select the essence and discard the dross to promote their own cultural qualities.

College English teaching is supposed to cover the whole college period from the angle of general education. The curriculum arrangement should be included during the whole period. The required English courses are established during the first and second academic year. The optional courses are established during the third academic year and the extended courses are established during the fourth academic year. The required and extended courses can include subjects on English and American literature appreciation, English and American films appreciation, English and American culture, western civilization and culture, etc. These courses meet with students' requirement for knowledge and stimulate their interest in English.

6) To adopt diverse teaching methods:Students should not only be equipped with rational structure of knowledge and abilities but also observe and think about the world in their own unique thinking way[5]. The traditional teaching way of college English is one-way implanted teaching centered on teachers, which is apt to make students bored with learning and is unfavorable to students' cultivation of cultural qualities and innovative abilities. In addition, the class with more students will also affect the teaching result. The teacher is the designer of class and designs diverse teaching methods, such as group discussion, role play, situational imitation, individual presentation,etc.to invigorate class atmosphere and remove students' fears of English class. Thus students are willing to get involved in the class activities in which the environment for communicating is established so that the communication among students as well as between students and teachers can be promoted. What's more, students' teamwork consciousness is enhanced and their creativity is cultivated.

\section{DifFICUlties EMERGED As THE GENERAL EDUCATION IDEA APPLIED TO COLLEGE ENGLISH TEACHING}

College English teaching guided by the general education idea has not won acknowledgement and adequate attention in many universities up to now because these universities still give priority to students' specialities and professional skills as well as examination skills. In the long run, we can see general education's role in students and society while general education cannot produce an immediate effect in the short run. Thus from the angle of universities, the application of the general education idea to college English teaching cannot get the support or policy guarantee to some extent.

Besides, if the general education idea is applied to college English teaching, it is necessary for universities to increase the compound faculty. A college English teacher with general education idea should not only improve their speciality attainments but also keep studying cross-specialty knowledge with the times and do research into a set of feasible teaching plans to improve the teaching quality. Therefore, except that teachers learn by themselves, universities should also offer regular training for teachers, strengthen English teachers' communication at home and abroad or hold English teachers' seminars, renewing teachers' knowledge structure in time, etc. These measures will broaden teachers' knowledge and enrich teachers' cross-culture knowledge system. Obviously it is necessary for universities and teachers themselves to prepare teaching in finances and energies, which is another difficulty we often meet in the course of practising such idea.

In general, the general education idea's application in college English teaching doesn't only rely on teachers' own efforts in which teachers add some general education contents to teaching, but also rely on universities' support and system guarateen. Teachers should cooperate with each other and bring general education into line with teaching plans, which need to be designed with delicacy and be perfected gradually so as to form a systematic teaching system.

Some difficulties may emerge. However, whether from the angle of students' requirement or society's need, it is workable to apply the general education idea to college English teaching.The general education idea can promote students' comprehensive and communicating abilities and influence students' learning motives. Guided by the general education idea, students tend to abandon the concept of instrumentalism and pragmatism and study college English as a course which contributes to individuals' balanced development of reason and perception and promoting their cultural attainments.

\section{REFERENCES}

[1] The College Foreign Language Teaching Guidance Committee of Higher Institutions in Education Ministry. The College English Teaching

Guidance[OL].http://wyx.zzia.edu.cn/picture/article/11/a1/46/4be21960 4bd4b253303fc53b48c1/6055feeb-9aa3-419f-9a35-1487c02ef8bb.pdf (read on 20th April, 2016).

[2] Li Manli. General Education — a Kind of University Education Viewpoints[M].Beijing: Qinghua University Press, 1999.

[3] Qian Ming. The General Educational Function of College English Courses - Enlightenment from Yale University Report in 1828 [J]. Education and Teaching Research,2014(9).

[4] Jin Yule. A Brief Argument on Potential Courses[J]. Curriculum Textbooks Teaching Methods, 1993 (6).

[5] Dai Lili. A New Teaching View on College English Classrooms[M] Beijing: Books Publishing Press in China, 2013. 